Original Research

\title{
The Association of Body Mass Index, Physical Activity and Hypertension in Indonesia
}

\author{
Hodimatum Mahiroh, Erni Astutik and Rochmad Ardiansyah Pratama
}

Faculty of Public Health Universitas Airlangga

\begin{abstract}
Introduction: Hypertension can cause cardiovascular disease and it is still a serious global problem. The Prevalence of hypertension has increased every year. Some of the factors associated with hypertension are obesity and physical activity. The prevalence of obesity has increased every year and many people have lower levels of physical activity. This study aims to analyze the correlation between Body Mass Index (BMI), physical activity and hypertension in Indonesia.
\end{abstract}

Methods: This study used a cross-sectional study design using secondary data from the Indonesia Family Life Survey 5 (IFLS5) conducted in 2014 - 2015. The sample consisted of individuals in the households interviewed and 26,472 respondents fulfilled the criteria. The data was analyzed using multivariate logistic regression.

Results: The results showed that most of the respondents were of productive age. More than half of the respondents were female $(52.05 \%)$. The respondents who had hypertension totalled $22.63 \%$. After being controlled by the covariate variables, the results showed that the obese respondents had 4.08 times higher odds of experiencing hypertension compared to the normal respondents $(\mathrm{AOR}=$ $4.08,95 \% \mathrm{CI}=3.68-4.53$, p-value $=0.000$ ) and that the respondents who were overweight were 2.49 times likely to get hypertension compared to the respondents who were normal $(\mathrm{AOR}=2.49,95 \% \mathrm{CI}=2.32-2.67$, $\mathrm{p}$-value $=0.000)$. Meanwhile, the respondents with an underweight BMI were 0.58 times more likely to have hypertension compared to the respondents who were normal $(\mathrm{AOR}=0.58$, 95\% CI = 0.52-0.65, $\mathrm{p}$-value $=0.000$ ).

Conclusion: Individuals with a higher BMI will be more at risk of hypertension while physical activity is not related to hypertension. The government and health services need to increase the promotion of a healthy lifestyle, especially healthy diet programs, to encourage the population to maintain an ideal body weight and to reduce the rate of hypertension.

\section{ARTICLE HISTORY}

Received: April 16, 2019

Accepted: July 13, 2019

\section{KEYWORDS}

Hypertension; IFLS; BMI; Physical Activity

\section{CONTACT}

Erni Astutik

$\bowtie$ erniastutik@fkm.unair.ac.id $\equiv$ Faculty of Public Health Universitas Airlangga

Cite this as: Mahiroh, H., Astutik, E., \& Pratama, R. (2019). The Association of Body Mass Index, Physical Activity, and Hypertension in Indonesia. Jurnal Ners, 14(1), 16-22. doi:http://dx.doi.org/10.20473/jn.v13i1.12811

\section{INTRODUCTION}

Hypertension is a silent killer disease that causes serious and dangerous diseases in the community (WHO, 2013). Hypertension, or high blood pressure, is an increase of the systolic blood pressure of more than $140 \mathrm{mmHg}$ and of the diastolic blood pressure by more than $90 \mathrm{mmHg}$ taken via two measurements with an interval of five minutes when in a state of adequate rest or calm. Hypertension in the long term can cause damage to the kidneys, heart and brain if it is not detected early and treated (Kemenkes RI, 2013).
Globally, cardiovascular disease causes 17 million deaths every year. This is almost one-third of the total deaths, where 9.4 million deaths are due to complications from hypertension. Hypertension contributed to $45 \%$ of deaths due to heart disease and $51 \%$ of deaths due to stroke (WHO, 2013). In Indonesia, hypertension is a major challenge that often occurs in primary health care. The treatment for hypertension is often not sufficient even though there are many effective medicines available (Kemenkes RI, 2013). Indonesia has experienced an increase in the prevalence of hypertension based on the measurement results for people aged $\geq 18$ years in 2013 through to 2018, which went from $25.8 \%$ up 
to $34.1 \%$ (Kemenkes RI, 2018). There are many risk factors for hypertension. Some are modifiable and the rest are unmodifiable. The unmodifiable risk factors are age, gender, family history and genetics. Meanwhile, the modifiable risk factors include smoking habits, saturated fat consumption, salt consumption, the use of used cooking oil, drinking habits, obesity, a lack of physical activity, stress and the use of estrogen (Kemenkes RI, 2013).

BMI is one of the risk factors of hypertension. BMI is related to determining nutritional status. Nutritional status can be used to identify weight. Weight problems at an early age can risk various degenerative diseases in adulthood (Kemenkes RI, 2013). In addition to this, BMI is used as an adiposity index in terms of clinical research. Central abdominal adiposity or obesity proves that there is a relation between obese and the risk of hypertension (Mancini, et al., 2011). According to the results of a study conducted by Kembuan, Kandou \& Kaunang (2016) in Southeast Minahasa Regency, it showed that respondents who were obese (BMI> $30 \mathrm{~kg} / \mathrm{m} 2$ ) had a risk that was 3.4 times greater of developing hypertension than the respondents who were not obese. Similar to hypertension, abdominal obesity is also associated with an increased risk of cardiovascular disease. Diseases related to mechanical stress in the body are also associated with obesity due to the increase in weight (Visscher and Seidel in Crawford and Jeffery, 2006).

Another risk factor for hypertension is a lack of physical activity. A lack of physical activity and the availability of high-calorie foods can prompt the development of pathological conditions such as obesity and cardiovascular disease. Physical activity would help to reduce excessive weight and to improve the efficiency of the cardiovascular system and overall psychological condition of well-being (D'Isanto, Tiziana, et.al, 2017). According to research conducted by Sihombing Marice (2017), a sufficient level of physical activity was significantly associated with hypertension. In addition, low-risk physical activity was 1.61 times to prompt the development hypertension than high physical activity. Other studies have shown that low physical activity increases the risk by 3.5 times of obese hypertension in early adolescents (Rabaity and Sulchan, 2012).

Based on the previous studies, Body Mass Index and physical activity were significantly correlated with hypertension. Moreover, obese adults have a lower level of physical activity than those with a normal weight, so both factors possibly influence the incidence of hypertension (Fernandes and Zanesco, 2010). Hypertension is now considered to be a major public health problem and its prevalence has increased in 2018 in Indonesia. Therefore, to overcome this problem, this study has sought to determine the factors related to hypertension, which are modifiable: Body Mass Index and physical activity.

\section{MATERIALS AND METHODS}

The method used in this study was a cross-sectional study design executed by analyzing the secondary data of the Indonesia Family Life Survey 5 (IFLS5) conducted in 2014 - 2015. IFLS5 had a response rate of $90.7 \%$. The population of this study was individuals in households throughout Indonesia. The sample totaled about 26,472 respondents after excluding the missing data of 6,209 respondents.

The sampling technique used was multistage random sampling. IFLS is a survey conducted longitudinally. A sampling of IFLS1 was carried out by randomly selecting from the 13 provinces based on the sample in SUSENAS 1993. From there, 321 areas were chosen including both urban and rural areas. After that, from each area, 20 urban and 30 rural households were chosen randomly. Respondent in IFLS5 were individuals interviewed in IFLS1, IFLS2, IFLS3 and IFLS4 (Strauss, Witoelar, and Sikoki, 2016).

The dependent variable of this study was hypertension status as obtained from the guideline books. Hypertension status was based on the average blood pressure measurement of the respondent (us07a, us07b, us07c code) which was done three times. The respondents were claimed to have hypertension if their systolic blood pressure was $\geq 140 \mathrm{mmHg}$ and diastolic blood pressure was $\geq 90 \mathrm{mmHg}$. Blood pressure was measured using Omron meter version HEM-7203.The independent variables of this study were BMI and physical activity, as well as the characteristics of the respondents consisting of age, sex, education, marital status and smoking status. The BMI variable was divided into four categories: underweight $(<18.5$ $\mathrm{kg} / \mathrm{m} 2)$, normal (18.5-25 $\mathrm{kg} / \mathrm{m} 2)$, overweight $(25.01-29.99 \mathrm{~kg} / \mathrm{m} 2)$ and obese $(\geq 30 \mathrm{~kg} / \mathrm{m} 2)$. The physical activity variable was divided into three categories: low activity $(<600$ MET (Metabolic Equivalents)), moderate activity (600-3000 MET) and high activity ( $\geq 3000$ MET). The age of the respondents (age code) was categorized as productive age (15-64 years) and non-productive age ( $>64$ years). The sex variable (sex code) and marital status (marstat code) were selected as in the $3 \mathrm{~A}$ book. The education variable (d06 code) was the length of the education period taken by the respondents categorized into three; low education ( $<8$ years), moderate education (8-13 years) and high education ( $\geq 14$ years). The smoking status variable was determined based on the smoking habits of the respondents ( $\mathrm{km04}$ code). The respondents were claimed to be a smoker if they had smoking habits and claimed as not being a smoker if they did not have smoking habits and if they had never consumed tobacco (km01a code).

The data was analyzed using univariate, bivariate and multivariate techniques. Univariate analysis was performed to determine the frequency and distribution of the variables. Bivariate analysis was done used Chi square. Multivariate analysis was 
Table 1. Characteristics of the Respondents

\begin{tabular}{|c|c|c|c|c|c|c|}
\hline \multirow{3}{*}{ Variable } & \multicolumn{4}{|c|}{ Hypertension } & \multirow{3}{*}{$\begin{array}{c}\text { Total } \\
\text { (n) }\end{array}$} & \multirow{3}{*}{$\begin{array}{l}\text { Percentage } \\
\quad(\%)\end{array}$} \\
\hline & \multicolumn{2}{|c|}{$\begin{array}{c}\text { Yes } \\
\mathrm{n}=5,991(22.63 \%)\end{array}$} & \multicolumn{2}{|c|}{$\begin{array}{c}\text { No } \\
n=20,481(77.37 \%)\end{array}$} & & \\
\hline & (n) & (\%) & (n) & $(\%)$ & & \\
\hline \multicolumn{7}{|c|}{ Body Mass Index } \\
\hline Underweight & 381 & 11.64 & 2,892 & 88.36 & 3,273 & 100 \\
\hline Normal & 2,757 & 18.44 & 12,192 & 81.56 & 14,949 & 100 \\
\hline Overweight & 2,000 & 32.33 & 4,187 & 67.67 & 6,187 & 100 \\
\hline Obese & 853 & 41.35 & 1,210 & 58.65 & 2,063 & 100 \\
\hline \multicolumn{7}{|c|}{ Physical Activity } \\
\hline High & 2,269 & 22.61 & 7,767 & 77.39 & 5,682 & 100 \\
\hline Moderate & 2,490 & 23.15 & 8,264 & 76.85 & 10,754 & 100 \\
\hline Low & 1,232 & 21.68 & 4,450 & 78.32 & 10,036 & 100 \\
\hline \multicolumn{7}{|l|}{ Age (year) } \\
\hline $15-64$ & 5,172 & 20.57 & 19,975 & 79.43 & 25,147 & 100 \\
\hline$\geq 65$ & 819 & 61.81 & 506 & 38.19 & 1,325 & 100 \\
\hline \multicolumn{7}{|l|}{ Sex } \\
\hline Male & 2,877 & 22.66 & 9,817 & 77.34 & 12,694 & 100 \\
\hline Female & 3,114 & 22.60 & 10,664 & 77.40 & 13,778 & 100 \\
\hline \multicolumn{7}{|l|}{ Education } \\
\hline Low & 3,279 & $33.23 \mid$ & 6,588 & 66.77 & 9,867 & 100 \\
\hline Moderate & 2,136 & 15.79 & 11,391 & 84.21 & 13,527 & 100 \\
\hline High & 576 & 18.71 & 2,502 & 81.29 & 3,078 & 100 \\
\hline \multicolumn{7}{|l|}{ Marital Status } \\
\hline Yes & 4,574 & 23.80 & 14,646 & 76.20 & 19,220 & 100 \\
\hline No & 1,417 & 19.54 & 5,835 & 80.46 & 7,252 & 100 \\
\hline \multicolumn{7}{|c|}{ Smoking Status } \\
\hline Yes & 1,865 & 21.95 & 6,630 & 78.05 & 8,495 & 100 \\
\hline No & 4,126 & 22.95 & 13,851 & 77.05 & 17,977 & 100 \\
\hline
\end{tabular}

performed using multiple logistic regression tests to investigate the most dominant factors affecting the incidence rate of hypertension. The covariate variables that had a relationship with hypertension with a p-value $<0,25$ were included in the multivariate analysis. The backward method was used to select the variables. The confounding variables were assessed by issuing the covariate variables one by one. This part of the study started with the variable that had the largest $p$-value. After that, if there was a difference in the odds ratio of more than $10 \%$ before and after the covariate variable, the variable must be excluded from the model.

\section{RESULTS}

This study found that $22.63 \%$ of the respondents experienced hypertension and that $23.37 \%$ of them were overweight and $7.79 \%$ were obese. Only $37.91 \%$ of the respondents had a high level of physical activity. Meanwhile, $94.99 \%$ of the respondents were of a productive age and most of them were female, making up $52.05 \%$ of the respondents. The respondents who had achieved higher education made up $11.63 \%, 72.61 \%$ of them were married and $32.09 \%$ of the respondents smoked (Table 1).

Based on Table 2, bivariate analysis showed that obese respondents had a 3,12 times higher risk of hypertension compared to normal respondents $(\mathrm{OR}=3.12,95 \% \mathrm{CI}=2.83-3.43, \mathrm{p}$-value $=0.000)$. Meanwhile, the respondents who were overweight were 2.11 times likely to have hypertension compared to the respondents who were of a normal weight $(\mathrm{OR}=2.11,95 \% \mathrm{CI}=1.97-2.25$, p-value = 0.000). For respondents with underweight BMI had 0.58 times higher for experiencing hypertension compared with normal BMI $(\mathrm{OR}=0.58,95 \% \mathrm{CI}=$ $0.52-0.65, \mathrm{p}$-value $=0.000)$. Besides, there was no significant correlation between physical activity and the incidence of hypertension ( $p$-value> 0.05).

Multivariate analysis after being controlled by the covariate variables, it was found that obese respondents had a 4.08 times higher risk of hypertension compared to normal respondents $(\mathrm{AOR}=4.08,95 \% \mathrm{CI}=3.68-4.53, \mathrm{p}$-value $=0.000)$. Meanwhile, the respondents who were overweight were 2.49 times likely to have hypertension compared to the respondents who were of a normal weight $(\mathrm{AOR}=2.49,95 \% \mathrm{CI}=2.32-2.67, \mathrm{p}$-value $=$ 0.000 ). For respondents with underweight BMI had 0.58 times higher for experiencing hypertension compared with normal BMI $(\mathrm{AOR}=0.58,95 \% \mathrm{CI}=$ $0.52-0.65$, p-value $=0.000$ ). Moreover, there was no significant correlation between physical activity and the incidence of hypertension after being controlled by the covariate variables ( $p$-value> 0.05).

\section{DISCUSSION}

In this study, the prevalence of hypertension was $22.63 \%$. This number was lower than the Riskesdas data from 2018, where the prevalence was $34.1 \%$. The IFLS5 survey was conducted in 2014 - 2015. The data illustrates that the prevalence of hypertension in Indonesia has continued to increase. This increase 
Table 2. Crude Odds Ratio and the Adjusted Odds Ratio Showing the Correlation between the Independent Variables and Hypertension in Indonesia

\begin{tabular}{|c|c|c|c|c|c|c|c|c|}
\hline \multirow{3}{*}{ Variable } & \multicolumn{4}{|c|}{ Bivariate } & \multicolumn{4}{|c|}{ Multivariate } \\
\hline & \multirow{2}{*}{$\mathbf{O R}(\mathrm{a})$} & \multicolumn{2}{|c|}{$95 \% \mathrm{CI}$} & \multirow{2}{*}{ p value } & \multirow{2}{*}{$\operatorname{AOR}_{(b)}$} & \multicolumn{2}{|c|}{$95 \%$ CI } & \multirow{2}{*}{ p value } \\
\hline & & lower & upper & & & lower & upper & \\
\hline \multicolumn{9}{|l|}{ BMI } \\
\hline Normal & Reff. & & & & Reff. & & & \\
\hline Underweight & 0.58 & 0.52 & 0.65 & 0.000 & 0.48 & 0.43 & 0.55 & 0.000 \\
\hline Overweight & 2.11 & 1.97 & 2.25 & 0.000 & 2.49 & 2.32 & 2.67 & 0.000 \\
\hline Obese & 3.12 & 2.83 & 3.43 & 0.000 & 4.08 & 3.68 & 4.53 & 0.000 \\
\hline \multicolumn{9}{|l|}{ Physical Activity } \\
\hline High & Reff. & & & & Reff. & & & \\
\hline Moderate & 1.03 & 0.96 & 1.10 & 0.349 & 1.05 & 0.97 & 1.12 & 0.172 \\
\hline Low & 0.94 & 0.87 & 1.02 & 0.180 & 1.02 & 0.94 & 1.12 & 0.529 \\
\hline \multicolumn{9}{|l|}{ Age (year) } \\
\hline $15-64$ & Reff. & & & & Reff. & & & \\
\hline$\geq 65$ & 6.25 & 5.57 & 7.01 & 0.000 & 6.15 & 5.43 & 6.96 & 0.000 \\
\hline \multicolumn{9}{|l|}{ Sex } \\
\hline Female & Reff. & & & & Reff. & & & \\
\hline Male & 1.00 & 0.95 & 1.06 & 0.903 & 1.48 & 1.36 & 1.61 & 0.000 \\
\hline \multicolumn{9}{|l|}{ Education } \\
\hline High & Reff. & & & & Reff. & & & \\
\hline Moderate & 0.81 & 0.74 & 0.90 & 0.000 & 0.97 & 0.87 & 1.08 & 0.600 \\
\hline Low & 2.16 & 1.96 & 2.39 & 0.000 & 2.35 & 2.11 & 2.61 & 0.000 \\
\hline \multicolumn{9}{|l|}{ Marital Status } \\
\hline No & Reff. & & & & Reff. & & & \\
\hline Yes & 1.29 & 1.20 & 1.37 & 0.000 & 0.98 & 0.91 & 1.05 & 0.585 \\
\hline \multicolumn{9}{|l|}{ Smoking Status } \\
\hline No & Reff. & & & & Reff. & & & \\
\hline Yes & 0.94 & 0.88 & 1.00 & 0.070 & 0.87 & 0.80 & 0.95 & 0.002 \\
\hline
\end{tabular}

Controlled by age, sex, education, marital status, and smoking status

$a=$ Odds Ratio

$b=$ Adjusted Odds Ratio

has been caused by changes in the lifestyle of Indonesian people such as smoking, eating foods that are high in fat, stress, obesity and a lack of exercise (RSUP Dr. Sardjito, 2018). The prevalence of hypertension in Indonesia was also lower than that of India, which was $31.4 \%$. India is a developing country just like Indonesia (WHO, 2017). However, hypertension is still a health problem in Indonesia. This study also found that $23.37 \%$ of respondents were overweight and that $7.79 \%$ were obese. This result was lower than the results of the research conducted by Sari et. al (2018), in which $62.5 \%$ of respondents were overweight. Meanwhile in the Riskesdas data of 2018, $13.6 \%$ of respondents were overweight and $21.8 \%$ of respondents were obese.

The results of the multivariate analysis showed that the respondents who were obese were 4.08 more likely to experience hypertension than the respondents with a normal weight. This result was higher than the research conducted in Uzbekistan which consisted of the Uzbekistan Health Screening Survey. Obese men were only 3.01 times more at risk of developing hypertension compared to the normal respondents. On the other hand, obese women were 2.82 times more at risk of developing hypertension compared to the normal respondents (Mishra, Arnold, Semenov, Hong, Mukuria, 2006). Research by Mbolle, B.F.E, et. al (2014) showed obesity associated factor of prehypertension (pre-HT) and hypertension (HT) (p value $=0,004)$. Research conducted by Forman, J.P., Stampfer, M.J., and Curhan, G.C. (2009) also showed that obese women were 4.70 times more at risk of developing hypertension compared to women with a BMI <23.0. This was supported by the research conducted by Sebayang (2017) which claimed that women were more likely to access health services than men. Another study conducted by Shuger, Sui, Church, Meriwether, and Blair (2008) showed that women who were overweight were 2.01 times more at risk of hypertension than women with a normal weight. As their BMI increased, so did their central obesity also increase (Kasyani, Sustyowati, and Kandarina, B.J.I, 2017). Research by Amanda and Martini (2017) also showed that the respondents with central obesity were 2.56 times more likely to have hypertension compared to respondents without central obesity.

Obesity is associated with hypertension because insulin has the ability to induce sodium retention. Insulin resistance caused chronic sodium retention. Based on the research that has been done, obese adolescents had selective insulin resistance so they were resistant to stimulate glucose absorption and still sensitive to the renal sodium-retaining effect of insulin (Rocchini, 2002). Meanwhile, someone who is obese needs more blood to supply oxygen and nutrition to their bodily tissues, so the volume of 
blood in the blood vessels increases. This means that the cardiac output increases and eventually, so too does the blood pressure (Sheps SG. In Sulastri, Elmatris, Ramadhani, 2012). Being overweight also increases insulin levels, which causes sodium retention in the kidneys. This also causes the blood pressure to increase (Morrison R. in Sulastri, Elmatris, Ramadhani, 2012). The effect of excessive weight on blood pressure is related to fat deposits in the body. The heart of overweight people works harder to pump blood because of the fat in the body clamping the blood vessels. In addition, for overweight people, the body also works hard to burn calories as the process requires an adequate oxygen supply. The more calories are burned, the greater the supply of oxygen needed. This causes the heart to work harder and for the person to experience an increase in blood pressure (Widharto in Mardani, Gustina, Dewanto, and Priwahyuni, 2011).

In this study, physical activity factors were not significant with the $p$-value $=0.172$ for moderate activity and the $p$-value $=0.529$ for low activity. This result was not in accordance with the research conducted by Chataut, Adhikari and Sinha (2011) in which the respondents with moderate physical activity showed significant results with the p-value = 0.00 . In the study, the respondents with a moderate level of physical activity were 2.44 times at risk of developing hypertension than the respondents with a high level of physical activity. A study conducted by Hasanudin, Adiyani and Perwiraningtyas, (2018) also stated that there was a significant correlation between physical activity and blood pressure in the society of Kelurahan Tlogomas, Lowokwaru in Malang City with the p-value $=0.005$. However, research conducted by Fernandes and Zanesco (2010) showed that current physical activity was not significantly related to the incidence rate of hypertension after adjusting for the confounding factors where the $p$-value $=0.815$. The measurement of physical activity should be conducted for at least nine months to avoid bias (Fernandes and Zanesco, 2010).

In theory, individuals who were active in terms of physical activity had low levels of morbidity and mortality. This is because physical activity plays a role in reducing the pathological adverse effects including arterial hypertension, metabolic syndrome and type 2 diabetes mellitus (Fernandes and Zanesco, 2010). In addition, individuals with a low level of physical activity were at risk of developing hypertension due to a lack of energy expenditure (Sugianti in Sihombing Marice, 2017). Researchers in America explained that physical activity carried out for at least 15 minutes a day can reduce $14 \%$ of the risk of obesity hypertension (Rabaity and Sulchan, 2012). Meanwhile, the physical activity factor in this study was not correlated significantly with hypertension because the researcher did not measure physical activity for at least nine months and they did not conduct a control history of the hypertension variable. BMI is a powerful confounder in the multivariate model. When it inserted into the analysis, current physical activity was not associated with hypertension (Fernandes and Zanesco, 2010).

The strength of this study was in the large sample. It represents $83 \%$ of the population in Indonesia. Thus, the bias can be minimized because it used the secondary data from IFLS5. In addition, the data was obtained through the measurement of the respondents' right and left arms repeated three times. This was to ensure that the data obtained was more valid. In this study, the researchers did not control for the history of hypertension variables which might influence changes in physical activity behavior before the measurements were made. For further research, it is suggested to examine the variables of hypertension history and other variables which are predicted to be related to hypertension, such as the respondent's diet.

Things that you can do to treat hypertension include modifying your lifestyle. Individuals who commit to a healthy lifestyle are less likely to experience hypertension (Forman, J.P., Stampfer, M.J., and Curhan, G.C., 2009). A healthy lifestyle includes having a healthy diet. A healthy diet is focused on maintaining weight by eating enough fruit, and salt and fat to a low degree. Government and public health services need to increase the promotion of a healthy lifestyle in society to reduce the rate of hypertension. These efforts can be carried out through improving the management of noncommunicable disease control services comprehensively, especially promotive and preventive control services in particular.

\section{CONCLUSION}

Hypertension is a dangerous disease for the wider community. BMI factors are significantly associated with the incidence rate of hypertension. The higher the BMI, the greater the risk for hypertension. Meanwhile, the factor of physical activity is not significantly related to the incidence of hypertension. Government and health services need to increase the promotion of healthy lifestyles especially about healthy diet program to maintain an ideal body weight and to reduce the rate of hypertension.

\section{REFERENCES}

Amanda, D. \& Martini, S. (2018). Hubungan Karakteristik dan Obesitas Sentral dengan Kejadian Hipertensi. Jurnal Berkala Epidemiologi, 6(1). [Accesed 2019 March 22]. DOI: 10.20473/jbe.v6i12018.43-50

Chataut, Adhikari, \& Sinha. (2011). Prevalence and Risk Factors for Hypertension in Adults Living in Central Development Region of Nepal. Kathmandu Univ Med J, 9(1), 13-18. [Accesed 2019 March 23]. Available from https://doi.org/10.3126/kumj.v9i1.6255 
Crawford, D. \& Jeffery, R.W. (2006). Obesity Prevention and Public Health. New York: Oxford University Press. DOI: 10.1136/adc.2006.095372

D'Isanto, Tiziana, et al. (2017). Health and Physical Activity. Sport Science, (10)1, 100-105.

Fernandes, R. A. \& Zanesco, A. (2010). Early Physical Activity Promotes Lower Prevalence of Chronic Diseases in Adulthood. Hypertension Research. [Accesed 2019 March 21]. Available from https://doi.org/10.1038/hr.2010.106

Forman, J.P., Stampfer, M.J., \& Curhan, G.C. (2009). Diet and Lifestyle Risk Factors Assosiated with Incident Hypertension in Women. American Medical Association, 302(4), 401-411. [Accesed 2019 March 27]. Available from https://doi.org/10.1001/jama.2009.1060

Hasanudin, Ardiyani, V.M., \& Perwiraningtyas, P. (2018). Hubungan Aktivitas Fisik dengan Tekanan Darah pada Masyarakat Penderita Hipertensi di Wilayah Tlogosuryo Kelurahan Tlogomas Kecamatan Lowokwaru Kota Malang. Nursing News, 3(1), 787-799

Kasyani, Sustyowati, \& Kandarina, B.J.I. (2017). Lingkar Pinggang dan Hipertensi pada Orang Indonesia Usia 40 Tahun ke Atas. Seminar Nasional Kesehatan Masyarakat Sriwijaya. [Accesed 2019 March 27].

Kembuan, Kandou, \& Kaunang. (2015). Hubungan Obesitas dengan Penyakit Hipertensi pada Pasien Poliklinik Puskesmas Touluaan Kabupataen Minahasa Tenggara. Fakultas Kesehatan Masyarakat Universitas Sam Ratulangi, 16-35. http://dx.doi.org/10.20473/jbe.V6I12018.35-42

Kemenkes RI. (2018). Hasil Riskesdas 2018. Jakarta. [Accesed 2019 March 25]. Available from www.depkes.go.id.

Kemenkes RI. (2013). Hasil Riskesdas 2013. Jakarta. [Accesed 2019 March 26]. Available from www.depkes.go.id

Kemenkes RI. (2013). Infodatin Hipertensi. Jakarta. [Accesed 2019 March 28]. Available from www.depkes.go.id

Mancini, et al. (2011). Nutritional and Metabolic Bases of Cardiovascular Disease. United Kingdom: UK Copyright, Designs and Patents Act 1988. DOI:10.1002/9781444318456

Mardani, Said, et al. (2011). Hubungan antara Indeks Massa Tubuh (IMT) dan Kebiasaan Mengonsumsi Lemak dengan Tekanan Darah. Jurnal Kesehatan Komunitas,

(1)3,

129-135. https://doi.org/10.25311/jkk.Vol1.Iss3.17

Mbolla, B.F.E., et al. (2014). Prehypertension and Hypertension among Schoolchildren in Brazzaville, Congo. International Journal of Hypertension. [Accesed 2019 March 25]. Available http://dx.doi.org/10.1155/2014/803690

Mishra, V, et al. (2006). Epidemiology of Obesity and Hypertension an Related Risk Factors in Uzbekistan. European Journal of Clinical Nutrition, (60), 1355-1366. [Accesed 2019 March
26].

Available

from

https://doi.org/10.1038/sj.ejcn.1602465

Morrison, R. (2006). The Zucker Rat as a Model of Obesity-Hypertension. Thesis, University of Marshall. Huntington, USA, 20-7. [Accesed 2019 March 23]. DOI: 10.1161/01.hyp.13.6.896

Rabaity, A. \& Sulchan, M. (2012). Konsumsi Gula Sederhana dan Aktivitas Fisik sebagai Faktor Risiko Kejadian Hipertensi Obesitik pada Remaja Awal. Journal of Nutrition College, 1(1), 185-191. [Accesed 2019 March 24]. https://doi.org/10.14710/jnc.v1i1.674

RSUP Dr. Sardjito. (2018). Pencegahan Penyakit Hipertensi dengan Gaya Hidup Sehat dan Peningkatan Pengetahuan tentang Hipertensi. [Accesed 2019 March 25].

Rocchini. (2002). Obesity Hypertension. American Journal of Hypertension, 15, 50S-52S. [Accesed 2019 March 26]. Available from https://doi.org/10.1016/S0895-7061(01)022993

Sari, Nilam Yusika, et al. (2018). Demographical Factors, not Lifestyle Factors, Assosiated with the Increase of Random Blood Glucose in Coastal Areas. Jurnal Ners, (13)1. [Accesed 2019 March 26]. Available from http://dx.doi.org/10.20473/jn.v13i1.8148

Sebayang, S. K., et al. (2017). Health Care-Seeking Behaviour of Coastal Communities in Banyuwangi, Indonesia: Results of a CrossSectional Survey. Jurnal Ners, (12)1, 66-73. [Accesed 2019 March 26]. Available from http://dx.doi.org/10.20473/jn.v12i1.4439

Sheps SG. (2005). Mayo Clinic Hipertensi, Mengatasi Tekanan Darah Tinggi. Intisari Mediatama: Jakarta.

Shuger, S.L., et al. (2008). Body Mass Index as a Predictor of Hypertension Incidence Among Initially Healthy Normotensive Women. US National Library of Medicine National Institutes of Health. American Journal of Hypertension, (21)6, 613-619. [Accesed 2019 March 27]. Available from https://doi.org/10.1038/ajh.2008.169

Sihombing, M. (2017). Faktor yang Berhubungan dengan Hipertensi pada Penduduk Indonesia yang Menderita Diabetes Mellitus (Data Riskesdas 2013). Puslitbang Sumber Daya dan Pelayanan Kesehatan, 53-64. [Accesed 2019 March 29]. Available from http://dx.doi.org/10.22435/bpk.v45i1.5730.

Strauss J., Witoelar F., \& Sikoki B. (2016). The Fifth Wave of the Indonesia Family Life Survey: Overview and Field Report. [Accesed 2019 March 30].

Sulastri, Elmatris, \& Ramadhani. (2012). Hubungan Obesitas dengan Kejadian Hipertensi pada Masyarakat Etnik Minangkabau di Kota Padang. Majalah Kedokteran Andalas, (2)36, 188-201. [Accesed 2019 March 29]. Available from https://doi.org/10.22338/mka.v36.i2.p188201.2012 
H. MAHIROH ET AL.

Visscher, T.L.S \& Seidell, J.C. (2001). The Public Health Impact of Obesity. Ann Rev Public Health, 22, 75-355. [Accesed 2019 March 23]. Available from

https://doi.org/10.1146/annurev.publhealth.22. 1.355

WHO. (2013). A Global Brief on Hypertension. [Accesed 2019 March 23]. Available from https://www.who.int
WHO. (2017). Global Health Observatory Data Repository. [Accesed 2019 March 23]. Available from https://www.who.int

Widharto. (2007). Bahaya Hipertensi. Jakarta: Sunda Kelapa Pustaka. 